\title{
Peranan Strategi Perniagaan terhadap Hubungan Pendedahan Modal Intelek dalam Laporan Integrasi Kos Ekuiti: Laporan Integrasi oleh Syarikat Antarabangsa
}

(The Role of Business Strategy on the Relationship between Intellectual Capital Disclosure in Integrated Reporting and Cost of Equity by International Companies)

\author{
Aida Md Rashid, Noradiva Hamzah \& Mohamat Sabri Hassan
}

\section{ABSTRAK}

Pendedahan maklumat kewangan dan bukan kewangan memberi pengaruh yang signifikan kepada pembuatan keputusan pelaburan. Dalam ekonomi yang berasaskan pengetahuan, modal intelek merupakan maklumat bukan kewangan yang penting dalam memberi nilai sebenar syarikat dan meningkatkan daya saing dalam pasaran global. Hasil dapatan kajian lepas mendapati hubungan pendedahan modal intelek dan kos ekuiti adalah tidak konsisten. Penyelidik lepas merasakan pendedahan modal intelek dalam laporan tahunan sudah kurang relevan dalam menyampaikan maklumat prestasi sesebuah syarikat kepada pelabur. Keadaan ini disebabkan kesukaran untuk mengukur nilai modal intelek dalam laporan tahunan dan pendedahan maklumat kewangan dan bukan kewangan dilakukan secara berasingan. Selaras dengan perkembangan pelaporan korporat terkini, Laporan Integrasi (IR) diperkenalkan dengan menggabungkan laporan kewangan dan bukan kewangan yang menjadikan IR dikatakan mampu memberi nilai tambah kepada pelabur dalam proses pembuatan keputusan. Memandangkan IR merupakan bidang baharu dalam penyelidikan dan IR adalah lebih komprehensif daripada laporan konvensional, maka kajian ini penting untuk mengkaji pendedahan modal intelek dalam IR. Ciri-ciri syarikat yang pendedahan maklumat adalah strategi perniagaan pula dipilih kerana kajian mengenai hubungan antara strategi perniagaan dengan pendedahan modal intelek masih belum dijalankan. Kajian ini mempunyai dua objektif; pertama untuk mengkaji hubungan pendedahan modal intelek dalam IR ke atas kos ekuiti syarikat. Kedua, mengkaji peranan strategi perniagaan ke atas hubungan antara pendedahan modal intelek dalam IR dan kos ekuiti. Sampel kajian ini terdiri daripada IR syarikat yang tersenarai dalam Pangkalan Data International Integrated Reporting Council (IIRC). Kajian ini menggunakan analisis kandungan untuk mengukur tahap pendedahan modal intelek dan analisis regresi digunakan untuk menyiasat hubungan antara pendedahan modal intelek dan kos ekuiti dan peranan pemboleh ubah pemoderat terhadap hubungan tersebut. Hasil kajian mendapati tiada hubungan antara pendedahan modal intelek dan kos ekuiti. Namun begitu, hasil analisis selanjutnya mendapati strategi perniagaan berperanan sebagai pemoderat antara hubungan pendedahan modal intelek dalam IR dan kos ekuiti. Menariknya, analisis tambahan bagi kajian ini menunjukkan syarikat yang bersaiz besar dan menggunakan strategi pembezaan produk dalam industri berasaskan pengetahuan menanggung kos ekuiti yang berkurangan. Sebaliknya, analisis tambahan juga mendapati syarikat yang menggunakan strategi kepimpinan kos sama ada dalam industri berasaskan pengetahuan atau industri tradisional memperoleh kos ekuiti yang lebih tinggi. Hasil kajian ini relevan kepada Badan Pemantauan sama ada di peringkat antarabangsa atau di Malaysia seperti Bursa Malaysia dan Suruhanjaya Sekuriti Malaysia untuk menggalakkan penggunaan IR di kalangan syarikat ke arah pendedahan yang lebih telus kerana ia membawa kepada kecekapan pasaran modal.

Kata kunci: Strategi perniagaan; Pendedahan modal intelek; Laporan Integrasi; Kos Ekuiti

\section{ABSTRACT}

The disclosure of financial and non-financial information has a significant impact on investment decision making. In a knowledge-based economy, intellectual capital is a non-monetary information that is important in giving a company's true value and enhancing competitiveness in the global market. The findings of the previous study found that the relationship between intellectual capital disclosure and cost of equity was inconsistent. Therefore, past researchers have found that the exposure of intellectual capital in annual reports is less relevant in communicating a company's performance information to investors. This is due to the difficulty in measuring the value of intellectual capital in annual reports and the disclosure of financial and non-financial information separately. In line with the latest corporate reporting developments, Integrated Reporting (IR) is introduced by incorporating financial and non-financial reports that make IR more valuable to investors in the decision making process. As IR is a new field of research and more comprehensive than conventional reports, this study is important to study the disclosure of intellectual capital in IR. Characteristics of companies whose disclosures are business strategies have been chosen because studies of the relationship between business strategies and intellectual capital disclosures have not been carried out. This study has 
two objectives; first to examine the relationship of IR's exposure to IR on the cost of the company's equity. Second, examine the role of business strategies on the relationship between exposure to intellectual capital in IR and cost of equity. The sample of this study consists of the Integrated Reporting of companies listed in the International Integrated Reporting Council (IIRC) database. This study uses content analysis to measure the level of intellectual capital exposure and regression analysis is used to investigate the relationship between intellectual capital exposure and cost of equity and the role of moderators in these relationships. The results show that there is no relationship between the exposure to intellectual capital and the cost of equit. However, the results of the study further suggest that business strategies serve as a moderator between the relationship of intellectual capital exposure in IR and cost of equity. Interestingly, additional analysis of this study shows that large companies and use of product differentiation strategies in the knowledge-based industry have reduced cost of equity. On the other hand, additional analysis also found that companies that use leader cost strategies in either the knowledge-based industry or the traditional industry have higher cost of equity. The results of this study are relevant to the Monitoring Agency either internationally or in Malaysia such as the Bursa Malaysia and the Malaysian Securities Commission to encourage the use of IR among companies towards more transparent disclosure as it leads to capital market efficiency.

Keywords: Business strategy; Disclosure of intellectual capital; Integrated Report; Cost of Equity

\section{Pendahuluan}

Persekitaran perniagaan abad ke-21 telah berubah yang mana kejayaan perniagaan bukan hanya bergantung kepada aset kewangan atau aset fizikal tetapi ditentukan modal intelek. Modal intelek terdiri daripada pengetahuan, maklumat, teknologi, hak cipta, pengalaman, pembelajaran organisasi, hubungan dengan pelanggan dan jenama yang membolehkan nilai dicipta untuk syarikat (Stewart 1997). Modal intelek membolehkan syarikat mencipta kelebihan bersaing seterusnya membentuk nilai syarikat yang tersendiri (Bontis 1998; Carlucci et al. 2004). Bagi memastikan syarikat kekal bertahan dalam persekitaran perniagaan yang mencabar, syarikat perlu lebih memberi tumpuan kepada modal intelek (Choo \& Bontis 2002)

Pendedahan modal intelek diakui penting oleh pemegang saham bagi membuat keputusan berkaitan pelaburan. Kajian terdahulu membuktikan pendedahan maklumat modal intelek memberi kesan kepada nilai pasaran syarikat (Abdolmohammadi 2005), tahap ketelusan organisasi (Edvinsson 1997; Kim 2012), imej dan kredibiliti syarikat serta memberi kepuasan kepada pelanggan (Yolanda Ramirez Corcoles 2013). Bagaimanapun, pendedahan modal intelek yang bersifat sukarela ini mempunyai limitasi dan terhad. Kajian oleh Dumay (2016) dan Dumay \& Rooney (2011) mendapati laporan modal intelek menjadi kurang relevan dan tidak memberi impak kepada pasaran kewangan.

Seiiring dengan perkembangan pelaporan korporat, International Integrated Reporting Council (IIRC) telah memperkenalkan IR pada tahun 2013. IR adalah harapan baru untuk pelaporan modal intelek kerana menggabungkan enam komponen modal yang mana tiga daripadanya terdiri daripada komponen modal intelek iaitu modal insan, modal sosial dan hubungan dan modal struktur (Beattie \& Smith 2013).

Pelaporan sukarela secara amnya didorong oleh perundangan, tekanan politik, lembaga pengarah, saiz syarikat, strategi dan hala tuju perniagaan, jenis industri dan sebagainya (Adams 2002; Zeng et al. 2012). Justeru itu, kajian ini memilih faktor strategi perniagaan oleh syarikat yang membuat pendedahan modal intelek dalam IR. Strategi perniagaan merupakan salah satu modal intelek syarikat yang tidak dapat ditiru dan unik kerana syarikat mempunyai sumber yang berbeza-beza. Sesuatu strategi ditentukan bergantung kepada visi dan misi serta sumber syarikat seperti pengetahuan dan kemahiran yang dapat mempengaruhi hala tuju syarikat pada masa hadapan (Pitts \& Lei 2003). Menurut Porter (1980), syarikat dapat membentuk strategi hasil daripada analisis faktor persaingan. Strategi persaingan dapat membezakan syarikat sama ada menggunakan strategi berasaskan kepimpinan kos, pembezaan produk dan pasaran sasaran.

Pemilihan strategi perniagaan memberi kesan kepada pelaporan syarikat termasuk corak pelaporan modal intelek dalam IR. Syarikat yang menggunakan strategi pembezaan produk mempunyai lebih banyak maklumat perlu dilaporkan seperti keunikan dan kualiti produk, aktiviti penyelidikan dan pembangunan serta aktiviti hubungan dengan pelanggan. Oleh itu, pendedahan maklumat yang dibuat adalah lebih dan dapat mengurangkan jurang maklumat dengan pelabur seterusnya mengurangkan kos ekuiti. Sebaliknya, syarikat yang mengamalkan strategi kepimpinan kos mementingkan kecekapan pengeluaran produk dan penjimatan kos bagi mencapai keuntungan yang optimum. Syarikat ini cenderung membuat pendedahan yang kurang bagi menjimatkan kos pengumpulan maklumat. Keadaan ini menyebabkan berlaku asimetri maklumat yang tinggi dan menyebabkan kos ekuiti meningkat. Bagaimanapun, kajian mengenai hubungan antara strategi syarikat dengan pendedahan modal intelek masih belum dijalankan. Kajian ini penting untuk dilaksanakan bagi mengkaji hubungan strategi dengan syarikat yang membuat pendedahan modal intelek bagi menentukan strategi yang digunakan. Selain itu, strategi perniagaan juga dijangka mempunyai fungsi sebagai pemoderat terhadap hubungan pendedahan modal intelek dan kos ekuiti.

Kajian ini mempunyai dua objektif; pertama untuk menyiasat hubungan pendedahan modal intelek dalam IR ke atas kos ekuiti syarikat. Kajian ini penting untuk 
dijalankan memandangkan laporan menggunakan kerangka kerja IR masih di peringkat awal dan kajian yang dijalankan terhadapnya masih terhad. Kedua, mengkaji peranan strategi perniagaan ke atas hubungan antara pendedahan modal intelek dalam IR dan kos ekuiti. Pemilihan strategi perniagaan juga merupakan elemen baharu yang membolehkan hasil gabungan antara disiplin pengurusan strategik dalam bidang perakaunan dikaji dengan lebih lanjut.

Hasil kajian mendapati tiada hubungan antara pendedahan modal intelek dalam IR dan kos ekuiti. Namun begitu, hasil kajian selanjutnya mendapati strategi perniagaan berperanan sebagai pemoderat antara hubungan pendedahan modal intelek dalam IR dan kos ekuiti. Menariknya, analisis tambahan bagi kajian ini menunjukkan syarikat yang bersaiz besar dan menggunakan strategi pembezaan produk dalam industri berasaskan pengetahuan mendapat kos ekuiti yang berkurangan. Sebaliknya, syarikat yang menggunakan strategi kepimpinan kos sama ada dalam industri berasaskan pengetahuan atau industri tradisional memperoleh kos ekuiti yang lebih tinggi. Bahagian seterusnya akan membincangkan ulasan karya, pembentukan hipotesis kajian, metodologi kajian dan hasil kajian. Akhir sekali kesimpulan dan implikasi kajian turut dinyatakan.

\section{Ulasan Karya dan Hipotesis KaJian}

\section{PENDEDAHAN MODAL INTELEK DALAM LAPORAN INTEGRASI}

Modal intelektual adalah konsep yang luas daripada modal manusia dan merujuk kepada sumber bukan kewangan yang menentukan nilai dan persaingan syarikat perniagaan dan ekonomi negara. Pengetahuan yang dimiliki oleh individu dan organisasi terhasil daripada gabungan sumber dalaman syarikat menjadi sesuatu yang bernilai dinamakan 'modal intelek' (Sveiby 1997). Modal intelek merupakan sumber tidak ketara atau keupayaan syarikat yang boleh menyumbang kepada nilai masa hadapan tetapi bukan dalam bentuk fizikal atau kewangan (Lev 2001; Zigan et. al 2008). Kepentingan modal intelek dikaji sejak bertahun dahulu menekankan peranan modal intelek dalam menentukan persaingan perniagaan (Teece 2000). Modal intelek memberi banyak manfaat kepada syarikat dan negara. Ia adalah sumber penting yang dapat membentuk nilai dan kekayaan bukan sahaja di peringkat syarikat (Jameelah et al. 2015; Kalkan et al. 2014) tetapi juga sumber kekayaan ekonomi negara (Labra \& Sánchez 2013; Ståhle \& Bounfour 2008).

Pendedahan maklumat berkaitan modal intelek amat berguna kepada pemegang saham bagi mendapatkan nilai sebenar sesebuah organisasi untuk membuat keputusan berkaitan pelaburan. Pendedahan yang lebih banyak mengenai maklumat modal intelek seperti kepakaran, kemahiran pekerja, teknologi yang dimiliki syarikat pastinya membolehkan pelabur memberi penilaian yang lebih baik kepada syarikat. Maklumat ini berupaya memberi nilai tambah serta kelebihan bersaing kepada syarikat sekaligus memberi kesan kepada reputasi syarikat dan berupaya meningkatkan permodalan pasaran sesebuah syarikat (Abdolmohammadi 2005; Kalkan et al. 2014; Shih et al. 2010).

Selain itu, pendedahan sukarela berkaitan modal intelek yang dibuat dapat mengurangkan masalah asimetri maklumat yang berlaku dalam pasaran seterusnya dapat mengurangkan kos ekuiti syarikat. Kajian oleh Abhayawansa dan Mohamad Azim (2014) mendapati syarikat farmaseutikal di Bangladesh mengiktiraf kepentingan modal intelek dalam pembentukan proses nilai korporat dengan membuat lebih banyak pendedahan maklumat atau sub kategori modal intelek dilaporkan oleh syarikat farmaseutikal di Bangladesh berbanding syarikat Bangladesh secara umum.

Bagaimanapun, kajian terhadap laporan tahunan mendapati aspek pendedahan modal intelek masih belum memuaskan dan semakin diabaikan (Bhasin 2011; Dumay \& Rooney 2011; Dumay 2016). Menurut kajian oleh Bhasin (2011), pendedahan maklumat modal intelek oleh 16 syarikat teknologi maklumat di India menunjukkan pendedahan modal intelek kurang diberi keutamaan dan dilaporkan bagi tujuan kegunaan dalaman. Selain itu, syarikat juga kurang membuat pendedahan disebabkan kesukaran untuk mengenal pasti pengukuran modal intelek (Espinosa \& Trombetta 2007)dan enggan mendedahkan maklumat rahsia mengenai modal intelek secara berlebihan kerana bimbang hilang kelebihan bersaing (Schaper et al. 2017).

Seiring dengan perkembangan pelaporan korporat, IR diperkenalkan oleh International Integrated Reporting Council (IIRC) pada tahun 2013. Menurut IIRC, IR adalah proses komunikasi ringkas dan bersepadu mengenai strategi, tadbir urus, ganjaran, pengurusan dan prospek syarikat dalam menghasilkan penciptaan nilai dalam jangka pendek dan panjang kepada pemegang saham. Justeru itu, IR diharap dapat menyambung kesinambungan pendedahan modal intelek dalam pasaran kewangan (Dumay 2017).

IR masih di peringkat awal pelaksanaan dan bukti manfaat IR masih terhad. Kajian awal mendapati syarikat membuat pendedahan modal intelek dalam IR bertujuan untuk menambahbaik imej korporat. Syarikat mendedahkan maklumat kuantitatif yang terhad tetapi lebih menjurus kepada maklumat modal hubungan (Melloni 2015). Hasil temu bual bersama pakar daripada institusi Afrika Selatan mendapati kerangka kerja IR dilihat sebagai penambahbaikan terhadap laporan tahunan konvensional (Atkins \& Maroun 2015). Di samping itu, agenda IR turut memberi anjakan perubahan daripada sistem pasaran modal kewangan kepada sistem pasaran modal yang menyeluruh melalui pengenalan pelbagai modal dalam kerangka kerja IR (Coulson et al. 2015). Analisis menunjukkan syarikat yang mengamalkan IR yang lebih tinggi memberikan prestasi yang lebih baik dalam pasaran saham dan prestasi perakaunan (Lee \& Yeo 2016). Kajian oleh Setia et al. (2015) mendapati pelaksanaan IR di Afrika Selatan telah 
meningkatkan pendedahan maklumat modal insan, modal sosial dan perhubungan, modal natural dan modal intelek syarikat. Peningkatan ketara adalah pendedahan modal sosial dan hubungan berbanding modal yang lain.

Kajian lepas mengenal pasti antara ciri-ciri spesifik syarikat yang membuat pendedahan sukarela adalah seperti saiz firma audit (Souissi \& Khlif 2012) dan keuntungan firma serta sejarah penyenaraian syarikat dalam pasaran saham (Kolsi 2017). Memandangkan IR masih baru, masih banyak faktor yang mendorong pendedahan modal intelek yang belum dikaji. Sehubungan itu, kajian ini akan mengkaji hubungan strategi perniagaan dengan pendedahan modal intelek dalam IR. Perkara ini selaras dengan hasil kajian oleh Villiers et al. (2014) yang mencadangkan supaya kajian dibuat terhadap proses dalaman yang berlaku dalam organisasi yang menerima pakai amalan IR.

\section{PENDEDAHAN MODAL INTELEK DAN KOS EKUITI}

Kos ekuiti merujuk kepada pulangan pelaburan yang dijangka oleh pelabur atau pemegang kepentingan daripada pelaburan yang dibuat dalam sesebuah syarikat. Bagaimanapun, kadar pulangan biasanya dipengaruhi oleh risiko, pertumbuhan dan saiz syarikat. Kos ekuiti penting dalam pelbagai keputusan korporat kerana ia mempengaruhi komposisi struktur modal, operasi dan keuntungan syarikat.

Kos ekuiti juga mempunyai hubungan dengan pendedahan maklumat syarikat. Pendedahan maklumat yang relevan dapat mengurangkan asimetri maklumat seterusnya mengurangkan masalah ketidakcekapan penilaian syarikat oleh pelabur seterusnya mengurangkan kos ekuiti syarikat (Easley \& O'Hara 2004). Pendedahan korporat penting dalam pasaran modal yang cekap. Pasaran modal yang efisien bermaksud pasaran di mana harga semua sekuriti yang diperdagangkan mencerminkan semua maklumat yang tersedia. Kekurangan maklumat yang didedahkan oleh pengurusan kepada pelabur akan menyebabkan berlaku asimetri maklumat. Masalah asimetri maklumat menyebabkan kecairan berkurangan dan pasaran modal menjadi kurang efisien (Akerlof 1970). Berdasarkan Teori Pengisyaratan, bagi mengatasi masalah pasaran yang kurang efisiyen dan jurang perbezaan maklumat ini, syarikat memberi isyarat kepada pelabur dengan membuat lebih banyak pendedahan maklumat (Botosan 1997; Verrecchia 2001). Pendedahan maklumat yang banyak menjadikan saham lebih menarik kepada pelabur seterusnya dapat meningkatkan kecairan. Pasaran akan menjadi lebih efisyen dengan peningkatan nilai kecairan dan mengurangkan kos ekuiti.

Kajian yang meneliti kesan pendedahan modal intelek ke atas kos ekuiti antaranya oleh Boujelbene \& Affes (2013) dan Mangena et al. (2016). Kajian oleh Mangena et al. (2010) terhadap 126 syarikat di United Kingdom mendapati pendedahan maklumat modal intelek bagi semua kategori mempunyai hubungan negatif dengan kos ekuiti. Ini disokong oleh kajian yang dijalankan oleh Boujelbene \& Affes (2013) terhadap syarikat tersenarai di Perancis mendapati wujud hubungan yang signifikan dan negatif antara pendedahan modal intelek dengan dua komponen iaitu modal manusia dan struktur ke atas kos ekuiti. Bagaimanapun, kesan negatif pendedahan modal hubungan tidak dapat disahkan. Berdasarkan kajian berikut, syarikat akan membuat pendedahan sukarela apabila mengetahui kesan kepada prestasi atau manfaat yang akan diperolehi pada masa hadapan. Ini kerana pendedahan yang lebih banyak dapat mengatasi masalah asimetri maklumat seterusnya dapat mengurangkan kos ekuiti syarikat. Hipotesis pertama yang akan diuji adalah seperti berikut:

$\mathrm{H}_{1}$ : $\quad$ Tahap pendedahan modal intelek dalam IR mempunyai hubungan negatif dengan kos ekuiti

\section{PERANAN STRATEGI PERNIAGAAN DALAM HUBUNGAN PENDEDAHAN MODAL INTELEK DAN KOS EKUITI}

Strategi organisasi menentukan objektif, matlamat dan hala tuju syarikat. Menurut Roos (2005), pembentukan strategi merupakan hasil daripada pemikiran modal insan yang menyumbang kepada prestasi syarikat. Syarikat yang dapat menguruskan sumber dalaman akan mendapat prestasi perniagaan yang lebih baik (Teece et al. 2000). Strategi perniagaan sesebuah syarikat adalah berbeza dan unik bergantung kepada sumber dalaman yang dimiliki oleh sesebuah syarikat yang unik dan tidak boleh ditiru. Ini selaras dengan teori berasaskan sumber yang menyatakan syarikat memiliki sumber yang unik, sukar ditiru dan boleh digunakan untuk kelebihan bersaing (Barney 1991). Pemilihan strategi yang digunapakai oleh syarikat akan memberi kesan kepada corak pendedahan maklumat modal intelek yang berbeza sama ada lebih banyak pendedahan modal intelek akan dibuat atau sebaliknya. Kajian lepas mendapati strategi yang lebih baik akan memberi hasil prestasi yang lebih baik (Pitts dan Lei 2003). Ia membantu syarikat mengenal pasti faktor persaingan, peluang dan acaman industri seperti yang dicadangkan oleh Porter (1980). Model Porter membezakan tiga strategi perniagaan iaitu pembezaan produk, kepimpinan kos dan strategi tumpuan untuk mengatasi lima faktor paksaaan dalam industri seperti kuasa pembekal, kuasa pembeli, ancaman pengganti, persaingan industri dan halangan kemasukan (Porter 1980).

Strategi pembezaan produk adalah strategi yang digunakan untuk mempengaruhi pelanggan mengenai keunikan produk sebagai kelebihan bersaing antara produk lain. Strategi pembezaan produk bertujuan membentuk keadaan yang berbeza daripada pesaing dari aspek tertentu seperti imej jenama, ciri-ciri teknikal, perkhidmatan, rangkaian pasaran dan kualiti. Syarikat membuat pelaburan yang banyak dalam pembangunan dan penyelidikan bagi menghasilkan meningkatkan inovasi syarikat (Jermias 2008). Strategi kos pemimpin pula menekankan penjimatan kos berbanding pesaing tetapi tidak mengabaikan kualiti dan mutu produk atau perkhidmatan (Porter 1985). Kepimpinan kos memerlukan syarikat menjadi pengeluar produk atau perkhidmatan dengan kos terendah supaya keuntungan purata diperolehi walaupun harga yang dikenakan tidak melebihi harga purata industri. Strategi 
fokus pula melibatkan sama ada strategi pembezaan atau kepimpinan kos dalam segmen pasaran yang lebih kecil.

Kajian lepas menunjukkan strategi syarikat mempunyai hubungan positif dengan prestasi kewangan syarikat (Kalkan et al. 2014). Ini kerana bagi meningkatkan prestasi, syarikat memerlukan strategi yang spesifik yang dapat membantu menguruskan sumber dalaman bagi mendapat kelebihan bersaing (Mehri et al. 2013). Kajian oleh Parnell (2010) berkaitan perbandingan antara hubungan strategi dengan prestasi di negara Mexico, Peru dan Amerika Syarikat menunjukkan strategi inovasi mempunyai hubungan positif dengan prestasi syarikat. Selain itu, kajian oleh Teeratansirikool et al. (2013) terhadap 101 syarikat tersenarai di Thailand mendapati strategi kompetitif mempunyai hubungan positif dengan prestasi syarikat. Di samping itu, kajian juga mendapati strategi pembezaan produk dan perkhidmatan mempunyai hubungan signfikan dengan prestasi syarikat tetapi tidak bagi syarikat yang menggunakan strategi kepimpinan kos.

Strategi perniagaan yang dipilih memberi kesan kepada corak pelaporan sesebuah syarikat. Pendedahan maklumat yang lebih lengkap dapat mengurangkan masalah asimetri maklumat antara pengurusan dan pelabur. Ia memberi kesan kepada pengurangan kos ekuiti syarikat disebabkan risiko yang dijangka dapat dikurangkan. Sehingga kini, kajian yang mengkaji strategi dengan kos ekuiti modal adalah terhad. Dari segi hubungan strategi dan kos ekuiti, kajian boleh disandarkan dengan hasil kajian mengenai hubungan reputasi dan kos ekuiti. Kajian oleh Coa et al. (2015) terhadap hubungan reputasi syarikat dan kos ekuiti mendapati syarikat yang mempunyai reputasi yang lebih baik mempunyai kos ekuiti yang rendah. Melalui reputasi yang baik, keyakinan pelabur dapat ditingkatkan sekaligus meningkatkan kecairan saham dan mengurangkan kos ekuiti.

Dalam konteks strategi, syarikat yang memilih strategi pembezaan produk mementingkan reputasi yang tinggi dan membuat pelaburan yang lebih bagi tujuan inovasi untuk menghasilkan produk baharu dan unik. Seterusnya, syarikat akan membuat pendedahan yang lebih banyak mengenai aktiviti inovasi syarikat. Pendedahan yang banyak ini dapat mengurangkan masalah asimetri maklumat dan mengurangkan kos ekuiti syarikat.

Bagi syarikat yang menggunakan kepimpinan kos pula, syarikat lebih mementingkan kecekapan dan penjimatan kos serta kurang aktiviti inovasi dijalankan. Di samping itu, bagi tujuan pendedahan maklumat juga, sedikit maklumat dilaporkan dalam laporan tahunan kerana kurang aktiviti hendak dilaporkan menyebabkan berlaku asimetri maklumat yang tinggi seterusnya meningkatkan kos syarikat. Berdasarkan perbincangan di atas, strategi perniagaan mempunyai hubungan dengan pendedahan modal intelek dan turut mempengaruhi kos ekuiti. Sehubungan itu, hipotesis kedua yang akan diuji adalah seperti berikut:

$\mathrm{H}_{2}$ : $\quad$ Strategi perniagaan memoderat hubungan antara tahap pendedahan modal intelek dalam IR dan kos ekuiti

\section{Metodologi KaJIAN}

\section{PERSAMPELAN}

Kajian ini menggunakan data sekunder yang diperolehi daripada IR syarikat bagi tahun 2011 hingga tahun 2017 daripada pangkalan data IIRC. Bagi kajian ini, IR syarikat diperoleh secara elektronik daripada pangkalan data IIRC. Pangkalan data tersebut mengandungi IR oleh syarikat yang menggunapakai kerangka kerja IR dari seluruh negara. IR tersebut disediakan oleh syarikat-syarikat yang terdiri daripada 6 wilayah seluruh dunia iaitu Eropah, Amerika Selatan, Amerika Utara, Asia, Afrika, Australia. Seperti yang ditunjukkan pada Jadual 2, syarikat tersebut tergolong dalam 12 industri antaranya barang pengguna, kesihatan, teknologi, telekomunikasi, kewangan, minyak dan gas, hartanah dan utiliti. Secara keseluruhannya, terdapat 282 IR dalam pangkalan data IIRC bagi tahun 2011 hingga 2017. Bagaimanapun, daripada jumlah tersebut sebanyak 33 IR adalah dari syarikat tidak tersenarai dan 66 syarikat tidak mempunyai data dalam Institutional Brokers' Estimate

JADUAL 1. Populasi Kajian

\begin{tabular}{|c|c|c|c|c|}
\hline Bil. & Negara & $\begin{array}{l}\text { Bilangan } \\
\text { Syarikat }\end{array}$ & $\begin{array}{l}\text { Peratus } \\
(\%)\end{array}$ & $\begin{array}{l}\text { Bilangan IR } \\
\text { Yang Disemak }\end{array}$ \\
\hline 1. & Australia & 4 & 3.7 & 6 \\
\hline 2. & Brazil & 5 & 4.6 & 8 \\
\hline 3. & Kanada & 2 & 1.8 & 2 \\
\hline 4. & Denmark & 1 & 0.9 & 3 \\
\hline 5. & Perancis & 3 & 2.7 & 4 \\
\hline 6. & Jerman & 4 & 3.7 & 4 \\
\hline 7. & Greece & 1 & 0.9 & 1 \\
\hline 8. & China & 1 & 0.9 & 3 \\
\hline 9. & India & 1 & 0.9 & 1 \\
\hline 10. & Itali & 6 & 5.5 & 10 \\
\hline 11. & Jepun & 9 & 8.3 & 11 \\
\hline 12. & Korea & 2 & 1.8 & 3 \\
\hline 13. & Luxemborg & 1 & 0.9 & 1 \\
\hline 14. & Netherland & 7 & 6.4 & 18 \\
\hline 15. & New Zealand & 2 & 1.8 & 5 \\
\hline 16. & Rusia & 1 & 0.9 & 1 \\
\hline 17. & Singapura & 1 & 0.9 & 4 \\
\hline 18. & Afrika Selatan & 14 & 11.9 & 32 \\
\hline 19. & Sepanyol & 2 & 1.8 & 5 \\
\hline 20. & Switzerland & 4 & 4.6 & 5 \\
\hline 21. & Taiwan & 1 & 0.9 & 1 \\
\hline 22. & Turki & 1 & 0.9 & 1 \\
\hline 23. & $\begin{array}{l}\text { United } \\
\text { Kingdom }\end{array}$ & 32 & 29.4 & 48 \\
\hline \multirow[t]{2}{*}{24.} & $\begin{array}{l}\text { Amerika } \\
\text { Syarikat }\end{array}$ & 4 & 3.7 & 6 \\
\hline & Jumlah & 108 & 100 & 183 \\
\hline
\end{tabular}


JADUAL 2. Sampel Kajian Mengikut Industri

\begin{tabular}{|c|c|c|c|c|c|c|c|c|}
\hline \multirow{2}{*}{ Industri } & \multicolumn{7}{|c|}{ Tahun } & \multirow{2}{*}{ Jumlah } \\
\hline & 2011 & 2012 & 2013 & 2014 & 2015 & 2016 & 2017 & \\
\hline \multicolumn{9}{|c|}{ Panel A: Pemerhatian Penyelidikan } \\
\hline Pemerhatian & 32 & 16 & 23 & 35 & 38 & 29 & 10 & 183 \\
\hline Peratus $(\%)$ & 17.5 & 8.7 & 12.6 & 19.1 & 20.8 & 15.8 & 5.5 & 100 \\
\hline \multicolumn{9}{|c|}{ Panel B: Sampel berdasarkan Industri } \\
\hline Bahan asas & 7 & 1 & 4 & 4 & 6 & 3 & 0 & 25 \\
\hline Barangan pengguna & 4 & 2 & 4 & 5 & 6 & 4 & 1 & 26 \\
\hline Perkhidmatan & 0 & 2 & 2 & 4 & 3 & 1 & 2 & 14 \\
\hline Perkhidmatan kewangan & 8 & 3 & 4 & 10 & 10 & 13 & 2 & 50 \\
\hline Kesihatan & 4 & 2 & 2 & 1 & 2 & 1 & 1 & 13 \\
\hline Industri & 1 & 2 & 2 & 3 & 1 & 3 & 0 & 12 \\
\hline Perkhidmatan profesional & 0 & 0 & 0 & 2 & 2 & 0 & 0 & 4 \\
\hline Minyak dan gas & 3 & 1 & 2 & 2 & 1 & 1 & 0 & 10 \\
\hline Hartanah & 1 & 1 & 0 & 0 & 1 & 1 & 0 & 4 \\
\hline Teknologi & 1 & 0 & 0 & 1 & 3 & 0 & 0 & 5 \\
\hline Telekomunikasi & 2 & 0 & 1 & 1 & 2 & 1 & 1 & 8 \\
\hline Utiliti & 1 & 2 & 2 & 2 & 1 & 1 & 3 & 12 \\
\hline Jumlah & 32 & 16 & 23 & 35 & 38 & 29 & 10 & 183 \\
\hline
\end{tabular}

System (IBES). Kajian ini akan menggunakan baki laporan sebanyak 183 IR yang mewakili 108 syarikat antarabangsa. Jadual 1 menunjukkan jumlah syarikat tertinggi yang menyediakan IR iaitu sebanyak 32 syarikat adalah daripada United Kingdom dan diikuti sebanyak 11 daripada Afrika Selatan.

\section{PENGUKURAN PEMBOLEH UBAH}

Pemboleh ubah bersandar kajian merupakan kos ekuiti syarikat. Berdasarkan sorotan kajian, model penilaian dibangunkan bagi mengganggarkan kos ekuiti tersirat berdasarkan ramalan pendapatan purata penganalisis dan harga saham semasa. Model penilaian utama ialah modal penilaian pendapatan residual oleh Gebhardt et al. (2001), model pertumbuhan pendapatan tidak normal oleh Gode dan Mohanram (2003) dan model pertumbuhan pendapatan atau ubahsuai (Easton 2004). Model tersebut menggunakan harga pasaran semasa dan ramalan perolehan penganalisis dalam mengganggarkan kos ekuiti. Kajian ini menggunakan model pertumbuhan pendapatan yang memerlukan data iaitu harga saham dan ramalan perolehan penganalisis. Berdasarkan model pertumbuhan pendapatan (Easton 2004), formula kos ekuiti seperti berikut:

$$
\text { Kos Ekuiti }=\sqrt{\frac{e p s_{2}-e p s_{1}}{P_{0}}}
$$

Di mana eps ${ }_{2}$ adalah ramalan pendapatan sesaham oleh penganalisis untuk tahun ke 2 tahun syarikat, eps , adalah $_{1}$ ramalan pendapatan oleh penganalisis tahun pertama syarikat dan $\mathrm{P}_{0}$ adalah harga saham semasa. Kedua-dua

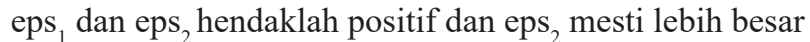
daripada eps $_{1}$ (Easton 2004). Harga saham dan ramalan pendapatan penganalisis diperoleh daripada Sistem Anggaran Antarabangsa Broker (I/B/E/S).

Pemboleh ubah tidak bersandar dalam kajian ini merupakan pendedahan maklumat modal intelek dalam IR. Tahap pendedahan maklumat diukur dengan menggunakan indeks pendedahan maklumat (Marston \& Shrives 1991). Dalam konteks modal intelek, tahap pendedahan modal intelek turut diukur menggunakan indeks pendedahan atau senarai semak yang dibangunkan oleh Li et al. (2008) yang mengandungi senarai maklumat modal intelek yang melibatkan 61 item. Senarai semak ini masih relevan digunakan walaupun dibangunkan pada tahun 2008 memandangkan senarai semak ini masih digunakan dalam kajian terkini oleh Mangena et al 2016. Teknik analisis kandungan ini digunakan untuk menilai pendedahan modal intelek dalam IR dalam kajian ini. Modal intelek terdiri daripada tiga komponen utama iaitu modal insan, modal hubungan dan modal struktur. Senarai Indeks Pendedahan Modal Intelek adalah seperti di Lampiran A. Skor pendedahan dalam kajian ini tidak mempunyai wajaran kerana tidak memberi fokus kepada kumpulan yang spesifik.

Unit analisis kajian merujuk kepada body of text yang dikira atau yang dianalisis seperti perkataan, ayat, perenggan atau keseluruhan laporan. Kajian ini menggunakan ayat dalam IR sebagai unit analisis. Pendekatan yang digunakan dalam kajian ini pada dasarnya adalah dikotomi yang mana satu item skor, "1" akan diberikan jika didedahkan dan "0". Tahap pendedahan modal intelek bagi setiap syarikat diukur dengan 
membahagikan jumlah skor yang diperolehi dengan jumlah skor yang dijangkakan akan diperolehi oleh sesebuah syarikat. tahap pendedahan maklumat modal intelek diukur dengan menggunakan formula seperti berikut:

Tahap pendedahan $=\frac{\text { Jumlah skor diperolehi oleh syarikat }}{\text { Jumlah skor maksimum yang dijangkakan }}$

Pemboleh ubah pemoderat bagi kajian ini iaitu strategi perniagaan. Kajian ini menggunakan definisi dan kriteria yang diberikan mengenai strategi Porter oleh Pitts dan Lei (2007) dan Dess dan Davis (1984) sebagai rujukan bagi menentukan jenis strategi yang digunakan sama ada syarikat menggunakan strategi pembezaan produk atau kepimpinan kosStrategi perniagaan dikenal pasti daripada pernyataan visi syarikat, slogan atau objektif syarikat yang terdapat dalam IR. Kaedah ini digunakan oleh kajian Noradiva Hamzah; Mohd Nazari Ismail 2008. Kata kunci bagi strategi pembezaan produk adalah seperti inovasi, unik, kualiti produk dan mengutamakan pelanggan manakala kata kunci strategi kepimpinan kos pula adalah kepimpinan kos, meningkatkan kecekapan, dan penjimatan kos. Pengukuran pemboleh ubah bagi strategi pembezaan produk ini adalah angka ' 1 ' manakala ' 0 ' bagi strategi kepimpinan kos.

Pemboleh ubah kawalan dalam kajian ini terdiri daripada lima pemboleh ubah, iaitu saiz syarikat, leveraj, nilai buku nilai pasaran, beta dan industri yang diambil berdasarkan kajian lepas. Saiz syarikat diukur menggunakan log jumlah aset (Orens et al. 2013; Boujelbene \& Affes 2013). Seterusnya, leveraj dipilih kerana dapat menggambarkan tahap risiko kewangan sesebuah syarikat (Mangena et al. 2016). Leveraj diukur berdasarkan nisbah jumlah hutang kepada jumlah aset. Pemboleh ubah kawalan ketiga adalah nilai pasaran ke nilai buku yang diukur sebagai nisbah permodalan pasaran dan nilai buku ekuiti syarikat (Orens et al. 2009; Boujelbene \& Affes 2013). Selain itu, beta merupakan faktor penting yang boleh mempengaruhi pendedahan maklumat sukarela (Haniffa \& Cooke 2005). Pemboleh ubah kawalan kelima adalah jenis industri (Haniffa \& Cooke 2005). Ini kerana syarikat cenderung membuat pendedahan maklumat pada tahap yang sama dengan syarikat lain yang beroperasi dalam industri yang sama bagi mengurangkan persaingan antara syarikat. Pengukuran pemboleh ubah jenis industri adalah ' 1 ' jika syarikat berintensif pengetahuan manakala ' 0 ' jika syarikat termasuk dalam industri tradisional. Industri berintensif pengetahuan terdiri daripada perkhidmatan kewangan, perkhidmatan profesional, teknologi, telekomunikasi, utiliti dan hartanah manakala industri tradisional pula meliputi sektor barangan pengguna, industri, minyak dan gas serta bahan asas (Mangena et al. 2016).

\section{Keputusan dan Perbincangan}

Analisis deskriptif menunjukkan taburan data untuk pemboleh ubah bersandar dan pemboleh ubah tidak bersandar terhadap 183 IR. Statistik deskriptif bagi semua pemboleh ubah adalah seperti di Jadual 3.

Berdasarkan Jadual 3, kos ekuiti menunjukkan purata kos ekuiti adalah berjumlah $4.389 \%$ manakala minimum kos ekuiti adalah $0.255 \%$ manakala nilai maksimum kos ekuiti adalah $62.709 \%$. Purata kos ekuiti tersebut adalah lebih rendah daripada yang dilaporkan oleh Mangena et al. (2016), iaitu 9.95\% bagi syarikat tersenarai di United Kingdom. Manakala kajian oleh Boujelbene dan Affes (2013) melaporkan purata kos ekuti adalah $9.364 \%$ bagi pasaran di Perancis berbanding kajian oleh Botosan (1997) yang menggunakan sampel syarikat di Amerika Syarikat mendapati purata kos ekuiti adalah $20.1 \%$.

Analisis deskriptif bagi pemboleh ubah tidak bersandar iaitu tahap pendedahan modal intelek menunjukkan secara purata tahap pendedahan modal intelek adalah $74.65 \%$. Tahap pendedahan modal intelek yang minimum adalah pada $29.51 \%$ manakala tahap pendedahan modal intelek yang maksimum adalah pada $90.16 \%$. Purata pendedahan modal intelek tersebut adalah lebih tinggi berbanding pendedahan modal intelek di pasaran United Kingdom iaitu $70.0 \%$ (Mangena et al. 2016) tetapi lebih rendah, iaitu 77\% daripada yang dilaporkan di Perancis oleh Boujelbene dan Affes (2013). Tahap pendedahan modal intelek terbahagi

JADUAL 3. Statistik deskriptif pemboleh ubah

\begin{tabular}{cccccc}
\hline Pemboleh ubah & Purata & Median & Sisihan Piawai & Minimum & Maksimum \\
\hline KME & 4.3893 & 1.8022 & 8.4853 & 0.2554 & 62.7097 \\
PMI & 0.7465 & 0.7541 & 0.0873 & 0.2951 & 0.9016 \\
SAIZ & 17.9954 & 17.6973 & 2.3819 & 13.5216 & 23.7512 \\
PMI*STRAT & 0.6818 & 0.7541 & 0.2332 & 0.0000 & 0.9016 \\
LEV & 0.2706 & 0.2408 & 0.1986 & 0.0086 & 0.9856 \\
Beta & 0.9066 & 0.9000 & 0.5107 & -0.0600 & 1.8300 \\
NPNB & 1.2748 & 0.8222 & 1.4993 & 0.0285 & 6.4248 \\
IND & 0.6776 & 1.0000 & 0.4687 & 0.0000 & 1.0000 \\
\hline
\end{tabular}

Di mana, KME adalah kos ekuiti; PMI adalah tahap pendedahan modal intelek; SAIZ ialah saiz syarikat (log jumlah aset); LEV ialah leveraj (jumlah liabiliti / jumlah aset); STRAT ialah strategi syarikat; BETA adalah risiko pasaran; NPNB ialah pasaran dipermodalkan; NPNB adalah permodalan pasaran dibahagi dengan nilai buku ekuiti; IND ialah jenis industri. 
kepada tiga kategori modal intelek iaitu modal insan, modal hubungan dan modal struktur. Rajah 1 menunjukkan syarikat lebih banyak membuat pendedahan modal insan, iaitu $78.4 \%$ diikuti dengan modal struktur, iaitu 77.5\% dan paling sedikit pendedahan modal hubungan iaitu $68.1 \%$.

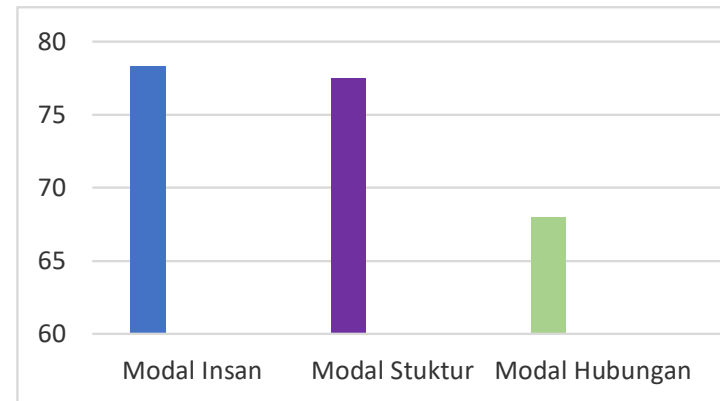

RAJAH 1. Tahap Pendedahan Modal Intelek Mengikut Kategori

Dapatan ini selaras dengan kajian oleh Abeysekera dan Guthrie (2005) yang menyatakan modal insan paling banyak dibuat pendedahan berbanding modal intelek yang lain. Modal hubungan didedahkan paling rendah disebabkan syarikat kurang membuat pendedahan berkaitan komitmen kontrak yang dilaksanakan. Ini selaras dengan hasil kajian oleh Schaper et al. (2017) yang menunjukkan syarikat di Denmark cenderung untuk menyimpan maklumat relevan berkaitan modal intelek disebabkan mereka tidak mahu berkongsi maklumat tersebut kepada pihak luaran. Di samping itu, kajian oleh Terblanche (2019) terhadap pendedahan modal intelek dalam IR bagi syarikat di Afrika
Selatan mendapati modal struktur dan modal hubungan lebih kurang dibuat pendedahan berbanding dengan modal manusia.

Analisis turut dibuat terhadap pendedahan maklumat modal intelek yang paling tinggi dilaporkan mengikut kategori seperti di Jadual 4. Bagi maklumat modal insan, maklumat yang paling banyak didedahkan adalah mengenai maklumat "latihan" oleh 182 syarikat atau 99.5\%. Ia diikuti dengan "diversiti pekerja, hubungan pekerja, kemahiran dan motivasi pekerja" masing-masing dilaporkan oleh 180 syarikat atau 98.4\%. Bagi modal struktur pula, maklumat "proses" dilaporkan oleh semua syarikat iaitu 100\% diikuti oleh maklumat "struktur organisasi, inovasi, teknologi dan budaya korporat". Modal struktur pula menunjukkan maklumat "pelanggan" paling tinggi dilaporkan iaitu 182 syarikat atau 99.5\%. Ia diikuti dengan maklumat "pemasaran, kerjasama perniagaan, hubungan dengan pembekal dan imej syarikat".

Analisis deskriptif turut dilaksanakan terhadap pendedahan modal intelek yang dilaksanakan mengikut negara yang dipilih. Rajah 2 menunjukkan perbandingan tahap pendedahan modal intelek yang dibuat mengikut negara. Purata indeks modal intelek yang tertinggi adalah negara India dengan skor 91.8\%. Bagaimanapun, purata indeks modal intelek bagi India adalah berdasarkan satu syarikat sahaja. Seterusnya, purata indeks modal intelek kedua tertinggi adalah negara Singapura $83.2 \%$ dan diikuti dengan negara China $82.0 \%$. Kanada mencatat skor purata indeks modal intelek terendah iaitu $43.4 \%$.

Analisis korelasi digunakan untuk menguji sama ada wujud masalah multikolineariti antara pemboleh ubah tidak bersandar dalam model kajian. Berdasarkan Jadual 5,

JADUAL 4. Pendedahan Modal Intelek Paling Tinggi Mengikut Kategori

\begin{tabular}{llllll}
\hline Modal Insan & $\%$ & Modal Struktur & $\%$ & Modal Hubungan & $\%$ \\
\hline Latihan Pekerja & 99.5 & Proses & 100.0 & Pelanggan & 99.5 \\
Diversiti Pekerja & 98.4 & Struktur Organisasi & 98.4 & Pemasaran & 98.4 \\
Hubungan Pekerja & 98.4 & Inovasi & 97.8 & Kerjasama Perniagaan & 97.3 \\
Kemahiran & 98.4 & Teknologi & 97.8 & Hubungan dengan pembekal & 94.5 \\
Motivasi Pekerja & 98.4 & Budaya Korporat & 97.3 & Imej Syarikat & 92.4 \\
\hline
\end{tabular}

JADUAL 5. Ujian Korelasi

\begin{tabular}{|c|c|c|c|c|c|c|c|c|c|}
\hline & $\operatorname{LnKME}$ & $P M I$ & BETA & $\# I N D$ & $L E V$ & $N P N B$ & SAIZ & \#STRAT & $P M I * S T R A T$ \\
\hline \multicolumn{10}{|l|}{ LnKME } \\
\hline$P M I$ & 0.0899 & & & & & & & & \\
\hline BETA & 0.0607 & 0.0058 & & & & & & & \\
\hline$I N D$ & 0.0772 & -0.0036 & $0.1967 * * *$ & & & & & & \\
\hline$L E V$ & -0.0854 & -0.1182 & $-0.2881 * * *$ & $-0.1799 * * *$ & & & & & \\
\hline $\operatorname{LnNPNB}$ & $0.1298 *$ & -0.0309 & -0.1101 & $-0.3226^{* * *}$ & $0.3819 * * *$ & & & & \\
\hline SAIZ & $0.2343 * * *$ & 0.0696 & $0.2946^{* * *}$ & $0.3111 * * *$ & $-0.2682 * * *$ & $-0.5034 * * *$ & & & \\
\hline STRAT & $0.1459 * *$ & $0.1740 * *$ & 0.1091 & $0.1417 * *$ & -0.1066 & -0.0493 & 0.0476 & & \\
\hline $\begin{array}{l}P M I * \\
\text { STRAT }\end{array}$ & $0.1598 * *$ & $0.4803 * * *$ & 0.0961 & $0.1347^{*}$ & $-0.1349^{*}$ & -0.0650 & 0.0726 & $0.9394 * * *$ & \\
\hline
\end{tabular}




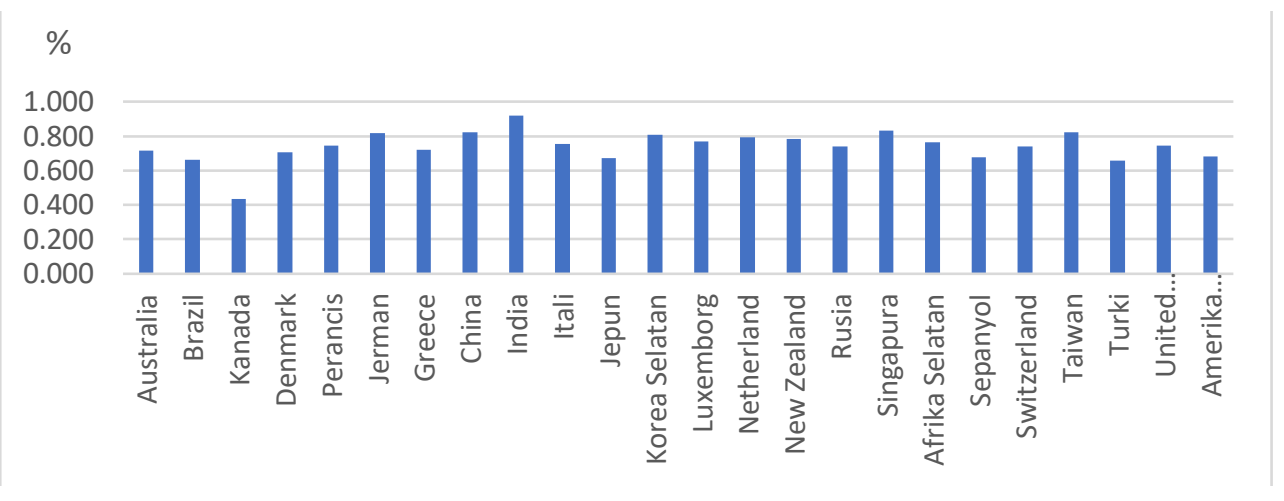

RAJAH 2. Purata Indeks Pendedahan Modal Intelek Mengikut Negara

pendedahan modal intelek (PMI) mempunyai hubungan secara positif dengan strategi (0.7140). Interaksi PMI dan strategi (STRAT) menunjukkan hubungan positif yang signifikan dengan kos ekuiti. Secara umumnya, tahap korelasi yang paling tinggi adalah hubungan antara interaksi PMI dan STRAT dengan pemboleh ubah strategi pada 0.9394 . Hubungan yang melebihi 0.8000 menandakan wujud masalah multikolineariti antara pemboleh ubah (Chua 2012; Tabachnick \& Fidell 2001). Dalam keadaan ini, pemboleh ubah STRAT akan dikeluarkan dalam analisis yang melibatkan pemboleh ubah interaksi PMI*STRAT di Jadual 5. Hanya pemboleh ubah interaksi PMI*STRAT dikekalkan dalam analisis regresi.

Hasil ujian regresi yang dilaksanakan untuk menguji hipotesis kajian ditunjukkan seperti di Jadual 6. Hipotesis pertama $\left(\mathrm{H}_{1}\right)$ bertujuan menyelidik hubungan langsung antara pendedahan modal intelek (PMI) dengan kos ekuiti (KME). Jadual 6 menunjukkan keputusan ujian regresi bagi menguji hubungan antara PMI dan KME. Analisis Model 1 menunjukkan PMI berhubung secara positif $(\beta=0.4984$, $\mathrm{t}=0.5766)$ dan tidak signifikan dengan kos ekuiti. Ini bermakna Hipotesis pertama tidak disokong. Pendedahan modal intelek tidak dapat mengurangkan kos ekuiti mungkin kerana tindakan syarikat membuat pendedahan modal intelek tidak memberi kesan kepada ketidaksamaratan maklumat yang dikehendaki oleh pelabur. Hasil dapatan ini selaras dengan kajian yang menyatakan kesan pendedahan maklumat ke atas kos ekuiti adalah bercampur (Espinosa \& Trombetta 2007; Souissi \& Khlif 2012). Antara faktor yang dikenalpasti adalah pemilihan polisi perakaunan syarikat (Espinosa \& Trombetta 2007) dan jenis maklumat yang didedahkan oleh syarikat (Souissi \& Khlif 2012).

Bagi hipotesis kedua pula, keputusan bagi peranan strategi sebagai pemoderat pula dilaporkan dalam Model 2 di Jadual 6. Pemboleh ubah STRAT dikeluarkan daripada model 2. Hasil ujian mendapati Model 2 menunjukkan PMI*STRAT mempunyai hubungan positif dan signifikan dengan KME pada tahap iaitu $\mathrm{p}<0.05$, iaitu $(\beta=0.6876$; $t=2.2985)$. Bagi model 2, didapati PMI dan KME mempunyai hubungan yang negatif tetapi interaksi PMI*STRAT yang berlaku (secara positif) telah memoderat hubungan langsung PMI dan KME. Pendedahan modal intelek oleh syarikat yang mengamalkan strategi pembezaan produk memberi kesan yang lemah dalam mengurangkan kos ekuiti. Dapatan ini menunjukkan peranan strategi perniagaan sebagai pemoderat hubungan antara PMI dan KME adalah disokong. Ini bermakna, Hipotesis 2 disokong.

JADUAL 6. Hasil Ujian Regresi

\begin{tabular}{lcc}
\hline Pemboleh ubah & Model 1 & Model 2 \\
\hline Konstan & -2.9355 & -2.5070 \\
& $(-2.4525)^{* *}$ & $(-2.0720)^{* *}$ \\
PMI & 0.4984 & -0.1079 \\
& $(0.5766)$ & $(-0.1148)$ \\
BETA & -0.1578 & -0.1563 \\
& $(-0.9434)$ & $(-0.9358)$ \\
LEV & -0.4702 & -0.4711 \\
& $(-1.6493)$ & $(-1.6542)^{*}$ \\
NPNB & 0.3242 & 0.3253 \\
& $(5.0257)^{* * *}$ & $(5.0317)^{* * *}$ \\
SAIZ & 0.1842 & 0.1841 \\
& $(3.5103)^{* * *}$ & $(3.5064)^{* * *}$ \\
STRAT & 0.4844 & \\
& $(2.1481)^{* *}$ & \\
IND & 0.1318 & 0.1288 \\
& $(0.6881)$ & $(0.6717)$ \\
PMI*STRAT & - & 0.6876 \\
R ${ }^{2}$ terlaras & & $(2.2985)^{* *}$ \\
Statistik F & 0.1427 & 0.1430 \\
$\mathrm{n}$ & 0.0000 & 0.0000 \\
\hline
\end{tabular}

Signifikan pada $0.01 * *$ signifikan pada $0.05 *$ signifikan pada 0.1

Kajian ini turut menjalankan analisis tambahan dengan membahagikan syarikat yang menggunakan strategi pembezaan produk dan strategi kepimpinan kos. Analisis ini dijalankan bagi memastikan sama ada strategi perniagaan dipengaruhi oleh faktor saiz firma dan jenis industri. Hasil ujian regresi yang dijalankan adalah seperti di Jadual 7. Panel A bagi strategi pembezaan produk menunjukkan PMI*SAIZ berhubung secara negatif dan 
JADUAL 7. Analisis Tambahan Mengikut Strategi Perniagaan

\begin{tabular}{|c|c|c|}
\hline Pemboleh ubah & Model 3 & Model 4 \\
\hline Panel A & \multicolumn{2}{|c|}{$\begin{array}{l}\text { Syarikat Menggunakan Strategi } \\
\text { Pembezaan Produk }\end{array}$} \\
\hline Konstan & $\begin{array}{c}-4.5475 \\
(-2.9061)^{* * *}\end{array}$ & $\begin{array}{c}-4.4475 \\
(-2.8086)^{* * *}\end{array}$ \\
\hline PMI & $\begin{array}{c}0.8687 \\
(0.8854)\end{array}$ & $\begin{array}{c}0.7570 \\
(0.7391)\end{array}$ \\
\hline BETA & $\begin{array}{l}-0.2371 \\
(-1.3329)\end{array}$ & $\begin{array}{l}-0.2337 \\
(-1.3089)\end{array}$ \\
\hline LEV & $\begin{array}{c}-0.5685 \\
(-1.9317)^{*}\end{array}$ & $\begin{array}{c}-0.5682 \\
(-1.9280)^{*}\end{array}$ \\
\hline NPNB & $\begin{array}{c}0.3383 \\
(5.1582)^{* * *}\end{array}$ & $\begin{array}{c}0.3351 \\
(5.0980)^{* * *}\end{array}$ \\
\hline IND & $\begin{array}{c}0.1335 \\
(0.6422)\end{array}$ & \\
\hline SAIZ & $\begin{array}{c}0.3118 \\
(4.1755)^{* * *}\end{array}$ & $\begin{array}{c}0.3118 \\
(4.1797)\end{array}$ \\
\hline PMI*SAIZ & $\begin{array}{c}-0.9746 \\
(-2.6403)^{* * *}\end{array}$ & $\begin{array}{c}-0.9685 \\
(-2.6154)^{* * *}\end{array}$ \\
\hline PMI*IND & & $\begin{array}{c}0.1329 \\
(0.4880)\end{array}$ \\
\hline $\mathrm{R}^{2}$ terlaras & 0.1664 & 0.1653 \\
\hline Statistik F & 0.0000 & 0.0000 \\
\hline $\mathrm{n}$ & 166 & 166 \\
\hline Panel B & \multicolumn{2}{|c|}{$\begin{array}{l}\text { Syarikat Menggunakan Strategi } \\
\text { Kepimpinan kos }\end{array}$} \\
\hline Konstan & $\begin{array}{c}3.9552 \\
(1.0203)\end{array}$ & $\begin{array}{c}3.9477 \\
(1.0085)\end{array}$ \\
\hline PMI & $\begin{array}{l}1.1002 \\
(0.5342)\end{array}$ & $\begin{array}{c}0.6216 \\
(0.3152)\end{array}$ \\
\hline BETA & $\begin{array}{l}-0.3013 \\
(-0.9186)\end{array}$ & $\begin{array}{l}-0.3128 \\
(-1.0032)\end{array}$ \\
\hline LEV & $\begin{array}{c}-2.3142 \\
(-2.0709)^{*}\end{array}$ & $\begin{array}{c}-2.3373 \\
(-2.1202)^{*}\end{array}$ \\
\hline NPNB & $\begin{array}{l}-0.0612 \\
(-0.3872)\end{array}$ & $\begin{array}{l}-0.0709 \\
(0.4315)\end{array}$ \\
\hline IND & $\begin{array}{c}1.1422 \\
(3.1064)^{* *}\end{array}$ & \\
\hline SAIZ & $\begin{array}{l}-0.2132 \\
(-1.3575)\end{array}$ & $\begin{array}{l}-0.1863 \\
(-1.1051)\end{array}$ \\
\hline PMI*SAIZ & $\begin{array}{c}0.7483 \\
(0.8794)\end{array}$ & $\begin{array}{c}0.5400 \\
(0.6028)\end{array}$ \\
\hline PMI*IND & & $\begin{array}{c}1.6486 \\
(3.3188)^{* * *}\end{array}$ \\
\hline $\mathrm{R}^{2}$ terlaras & 0.3096 & 0.3151 \\
\hline Statistik F & 0.0079 & 0.0051 \\
\hline $\mathrm{n}$ & 17 & 17 \\
\hline
\end{tabular}

Nota: *** Signifikan pada $0.01 * *$ signifikan pada $0.05 *$ signifikan pada 0.1 signifikan dengan kos ekuiti pada tahap $\mathrm{p}<0.01$ dalam Model 3 dan 4. Ini menunjukkan syarikat bersaiz besar yang menggunakan strategi pembezaan produk akan mendapat kos ekuiti yang rendah. Syarikat bersaiz besar mampu menyediakan sumber yang lebih banyak dari segi kewangan, tenaga kerja dan sistem yang lebih baik untuk membuat pendedahan modal intelek. Inovasi juga merupakan salah satu ciri-ciri strategi pembezaan produk. Kajian berkaitan inovasi dan saiz syarikat membuktikan bahawa inovasi mempunyai hubungan positif dengan syarikat bersaiz besar (Damanpour 1992; CamisónZornoza 2004). Syarikat bersaiz besar yang menggunakan strategi pembezaan produk cenderung membuat pendedahan yang lebih banyak mengenai maklumat produk dari segi jenama dan kualiti serta mementingkan hubungan dengan pelanggan bagi menjaga reputasi dan imej syarikat sebagai isyarat kepada pelabur. Oleh itu, pelabur akan mendapat lebih maklumat mengenai syarikat dan produk serta perkhidmatan syarikat ini. Keadaan ini dapat mengurangkan berlaku asimetri maklumat seterusnya mengurangkan kos ekuiti syarikat. Selain itu, pemboleh ubah lain seperti leveraj, nilai pasaran kepada nilai buku dan saiz syarikat adalah signifikan pada kadar yang tidak konsisten.

Bagi syarikat yang menggunakan strategi kepimpinan kos di Panel B pula, keputusan ujian menunjukkan IND berhubungan secara positif dan signifikan dengan kos ekuiti pada tahap $\mathrm{p}<0.01$ dalam Model 4, Jadual 7. Ini menunjukkan syarikat yang menggunakan strategi kepimpinan kos dalam industri berasaskan pengetahuan akan mendapat kos ekuiti yang lebih tinggi. Syarikat yang menggunakan strategi kepimpinan kos dalam industri berasaskan pengetahuan ini mementingkan kecekapan pengeluaran dan penjimatan kos. Syarikat ini cenderung membuat pendedahan yang kurang bagi menjimatkan kos pengumpulan maklumat. Oleh itu, syarikat yang menggunakan strategi kepimpinan kos walaupun dalam industri berasaskan pengetahuan membuat pendedahan yang kurang dan menyebabkan berlaku asimetri maklumat serta mengakibatkan kos ekuiti yang lebih tinggi.

Kesimpulannya, ujian regresi hipotesis kedua menunjukkan strategi pembezaan produk memoderat hubungan antara PMI dan KME. Analisis tambahan yang dijalankan mendapati syarikat bersaiz besar yang menggunakan strategi pembezaan produk membuat pendedahan modal intelek yang tinggi dalam IR mendapat kos ekuiti yang rendah. Bagi syarikat yang menggunakan strategi kepimpinan kos dalam industri pengetahuan pula cenderung membuat pendedahan modal intelek yang kurang dan menyebabkan syarikat mendapat kos ekuiti yang tinggi. Dapatan kajian ini merupakan antara kajian terawal yang menggabungkan strategi perniagaan dan tahap pendedahan modal intelek. 


\section{KESIMPULAN}

Kerangka kerja pendedahan maklumat bukan kewangan termasuk modal intelek yang diperkenalkan oleh IIRC masih baharu diadaptasi oleh syarikat pelbagai negara. Justeru itu, banyak faktor-faktor yang perlu dikaji oleh syarikat sebelum melaksanakan pendedahan maklumat kewangan dan bukan kewangan selaras dengan kerangka yang dianjurkan. Kajian ini mempunyai dua (2) objektif utama iaitu mengkaji hubungan pendedahan modal intelek dalam IR ke atas kos ekuiti. Objektif kedua pula adalah untuk mengkaji peranan strategi perniagaan ke atas hubungan pendedahan modal intelek dan kos ekuiti. Analisis regresi yang dijalankan terhadap 183 IR menunjukkan tiada hubungan signifikan antara pendedahan modal intelek dan kos ekuiti. Keadaan ini berbeza dengan dapatan kajian lepas yang mengkaji hubungan antara pendedahan modal intelek dan kos ekuiti dalam laporan tahunan yang mendapati wujud hubungan negatif yang signifikan antara pendedahan modal intelek dan kos ekuiti (Boujelbene \& Affes 2013; Mangena et al. 2016; Orens et al. 2009). Berdasarkan kajian lepas, wujud keadaan di mana dapatan kajian mengenai pendedahan modal intelek ke atas kos ekuiti memberi kesan yang bercampur antaranya disebabkan oleh pemilihan polisi perakaunan syarikat (Espinosa \& Trombetta 2007) dan persekitaran negara pelaporan dibuat serta bergantung kepada jenis pelaporan yang didedahkan (Souissi \& Khlif 2012). Di samping itu, keadaan ini mungkin disebabkan IR masih baharu diperkenalkan dan hanya sebilangan kecil syarikat yang menggunakan laporan tersebut bagi membuat pendedahan modal intelek. Selain itu, syarikat tidak konsisten dalam membuat pendedahan modal intelek dalam IR kerana beberapa syarikat tidak membuat pendedahan IR untuk tahun-tahun tertentu dalam pangkalan data IIRC. Kajian ini juga menggunakan sampel daripada pelbagai negara yang mana mempunyai persekitaran pelaporan yang berbeza.

Hasil kajian seterusnya mendapati strategi pembezaan produk berperanan sebagai pemoderat hubungan pendedahan modal intelek dan kos ekuiti. Analisis tambahan dijalankan dengan mengasingkan syarikat mengikut strategi perniagaan iaitu strategi pembezaan produk dan strategi kepimpinan kos. Dapatan analisis tambahan mendapati syarikat bersaiz besar yang menggunakan strategi pembezaan produk mengalami kos ekuiti yang rendah. Ini kerana syarikat bersaiz besar cenderung menggunakan strategi pembezaan produk bagi memaklumkan kepada pelabur ciri-ciri atau kualiti produk yang ditawarkan, aktiviti penyelidikan yang dijalankan dan hubungan pelanggan yang diutamakan melalui pendedahan maklumat modal intelek yang lebih banyak (Noradiva Hamzah \& Mohd Nazari Ismail 2007). Berdasarkan Teori Pengisyaratan, pendedahan maklumat yang banyak memberi petunjuk kepada pelabur mengenai maklumat modal intelek yang dimiliki oleh syarikat yang dapat mengurangkan masalah asimetri maklumat antara pelabur dan syarikat. Keadaan ini akan meningkatkan kecairan pasaran saham seterusnya memberi kesan kepada kos ekuiti yang rendah. Analisis tambahan turut mendapati syarikat yang menggunakan strategi kepimpinan kos dalam industri berasaskan pengetahuan pula mendapat kos ekuiti yang lebih tinggi. Ini kerana syarikat yang mengamalkan strategi kepimpinan kos mementingkan penjimatan kos pengeluaran dan pembuatan keputusan bilangan pendedahan maklumat dibuat berdasarkan analisis kos faedah kepada syarikat. Pendedahan maklumat hanya dibuat bagi maklumat penting dan memberi manfaat kepada syarikat dengan mengambil kita penjimatan kos. Pendedahan maklumat yang terhad menimbulkan masalah asimetri maklumat yang tinggi di kalangan pelabur. Keadaan ini menyebabkan syarikat perlu menanggung kos ekuiti yang tinggi. Kajian lepas yang mengkaji hubungan strategi perniagaan dan tahap pendedahan maklumat syarikat masih belum dijalankan. Oleh itu, kajian ini memberi sumbangan baharu dengan menggabungkan disiplin pengurusan strategik dan disiplin perakaunan.

Kajian ini mempunyai batasan-batasan berikut. Pertama saiz sampel adalah kecil di mana hanya 183 menyediakan maklumat modal intelek dalam IR. Pengurangan sampel turut berlaku apabila syarikat tidak mempunyai data dalam IBES. Kedua, analisis adalah hasil daripada data gabungan kerana syarikat tidak membuat pendedahan modal intelek yang konsisten dalam IR atau sesetengah syarikat mula membuat pendedahan modal intelek dalam IR dalam tahun terkemudian. Berdasarkan kekangan yang diberikan kajian ini boleh dikembangkan dengan menjalankan kajian lanjut. Antara cadangan kajian yang boleh dilaksanakan ialah mengkaji tahap pendedahan modal intelek dalam IR menggunakan panel data yang mana analisis panel data adalah lebih baik dalam menerangkan sesuatu keadaan. Kajian akan datang juga boleh melanjutkan kajian ini kepada kaedah kualitatif supaya lebih memahami keadaan yang tidak konsisten yang berlaku dalam pendedahan modal intelek antara syarikat. Peranan tadbir urus sebagai pemboleh ubah pemoderat dalam hubungan pendedahan modal intelek juga adalah relevan untuk dikaji pada masa akan datang.

\section{RUJUKAN}

Abdolmohammadi, M. J. 2005. Intellectual capital disclosure and market capitalization. Journal of Intellectual Capital 6(3): 397-416.

Abeysekera, I., \& Guthrie, J. 2005. An empirical investigation of annual reporting trends of intellectual capital in Sri Lanka. Critical Perspectives on Accounting 16(3): 151163.

Abhayawansa, S. \& Azim, M. 2014. Corporate reporting of intellectual capital: evidence from the Bangladeshi pharmaceutical sector. Asian Review of Accounting 22.

Adams, C. A. 2002. Internal organisational factors influencing corporate social and ethical reporting. Accounting, Auditing \& Accountability Journal 15(2): 223-250.

Arkelof, G. 1970. The markets for lemons: quality uncertainty and the market mechanism. The markets for lemons: quality uncertainty and the market mechanism 84(3): 488-500. 
Atkins, J. \& Maroun, W. 2015. Integrated reporting in South Africa in 2012. Meditari Accountancy Research 23(2): 197-221.

Barney, J. 1991. Firm resources and sustained competitive advantage. Journal of Management 17(1), 99-120.

Beattie, V. \& Smith, S. J. 2013. Value creation and business models: Refocusing the intellectual capital debate. British Accounting Review 45(4): 243-254.

Bhasin, M. L. 2011. Disclosure of Intellectual Capital in Annual Reports: An Empirical Study of the Indian IT Corporations. Modern Economy 2(4): 455-467.

Bontis, N. 1998. Intellectual capital : an exploratory study that develops measures and models. Management Decision 36(2): 63-76.

Botosan, C. A. 1997. Disclosure Level and the Cost of Equity Capital. The Accounting Review 72(3): 323-349.

Boujelbene, M. A. \& Affes, H. 2013. The impact of intellectual capital disclosure on cost of equity capital: A case of French firms. Journal of Economics, Finance and Administrative Science 18(34): 45-53.

Camisón-Zornoza, C., Lapiedra-Alcamí, R., Segarra-Ciprés, M., \& Boronat-Navarro, M. 2004. A meta-analysis of innovation and organizational size. Organization studies 25(3): 331-361.

Cao, Y., Myers, J. N., Myers, L. A. \& Omer, T. C. 2015. Company reputation and the cost of equity capital $42-81$.

Carlucci, D., Marr, B. \& Schiuma, G. 2004. The knowledge value chain: how intellectual capital impacts on business performance. Int. J. Technology Management 277(67): $575-590$

Choo, C. W. \& Bontis, N. 2002. Knowledge, Intellectual Capital, and Strategy.

Chua Yan Piaw. 2012. Asas Statistik Penyelidikan. Kuala Lumpur: Mc Graw Hill.

Coulson, A.B., Adams, C., Nugent, M. and Haynes, K. 2015. Exploring metaphors of capitals and the framing of multiple capitals: challenges and opportunities for IR. Sustainability Accounting, Management and Policy Journal 6(3): 290314.

Damanpour, F. 1992. Organizational size and innovation. Organization Studies 13(3): 375-402.

Diamond, D. W. \& Verrecchia, R. E. 1991. Disclosure, Liquidity, and the Cost of Capital. The Journal of Finance 46(4): $1325-1359$.

Dumay, J. 2016. A critical reflection on the future of intellectual capital: from reporting to disclosure. Journal of Intellectual Capital 17(1): 1-17.

Dumay. 2017. A critical reflection on the future of intellectual capital : from reporting to disclosure. Journal of Intellectual Capital January 2016)

Dumay, J. \& Rooney, J. 2011. "Measuring for managing?" An IC practice case study. Journal of Intellectual Capital 12(Ic): 344-355.

Easley, D. \& O'Hara, M. 2004. Information and the Cost of Capital Information and the Cost of Capital. The Journal Of Finance 59(4): 1553-1583.

Easton, P. D.2004. PE ratios, PEG ratios, and estimating the implied expected rate of return on equity capital. The accounting review 79(1): 73-95.

Edvinsson, L. 1997. Developing Intellectual Capital at Skandia 30(3).

Espinosa, M. \& Trombetta, M. 2007. Disclosure interactions and the cost of equity capital: Evidence from the Spanish continuous market. Journal of Business Finance and Accounting 34(9-10): 1371-1392.
Gebhardt, W. R., Lee, C. M. C. \& Swaminathan, B. 2001. Toward an Implied Cost of Capital. Journal of Accounting Research 39(1): 135-176.

Gode, D. \& Mohanram, P. 2003. Inferring the Cost of Capital Using the Ohlson - Juettner Model. Review of Accounting Studies 8: 399-431.

Haniffa, R. M. \& Cooke, T. E. 2005. The impact of culture and governance on corporate social reporting. Journal of Accounting and Public Policy 24(5): 391-430.

Jameelah, M., Osman, I. \& Musa, S. 2015. Effect of Intellectual Capital on Organizational Performance 211(September): 207-214.

Jermias, J. 2008. The relative influence of competitive intensity and business strategy on the relationship between financial leverage and performance. The British Accounting Review 40(1): 71-86.

Kalkan, A., Çetinkaya, Ö. \& Arman, M. 2014. The impacts of intellectual capital, innovation and organizational strategy on firm performance. Procedia - Social and Behavioral Sciences 150: 700-707.

Kim, B., 2012. Proactive self-disclosure of threats: The effects of voluntary disclosure of corporate issues on perceived organizational transparency, credibility, and perceived severity of issues (Doctoral dissertation, University of Missouri--Columbia).

Kolsi, M. C. 2017. The determinants of corporate voluntary disclosure policy. Journal of Accounting in Emerging Economies.

Labra, R. \& Sánchez, M. P. 2013. National intellectual capital assessment models: a literature review. Journal of Intellectual Capital 14: 582-607.

Lee, K. W. \& Yeo, G. H. H. 2016. The association between integrated reporting and firm valuation. Review of Quantitative Finance and Accounting 47(4): 1221-1250.

Lev, B. 2001. Intangibles - Management, Measurement, and Reporting. Brookings Institution Press Washington, DC

Li, J., Pike, R. and Haniffa, R. 2008. Intellectual capital disclosure and corporate governance structure in UK firms. Accounting and Business Research 38(2): 137-159.

Mangena, M., Li, J. \& Tauringana, V. 2016. Disentangling the Effects of Corporate Disclosure on the Cost of Equity Capital. Journal of Accounting, Auditing \& Finance 31(1): 3-27.

Mangena, M., Pike, R. \& Li, J. 2010. Intellectual Capital Disclosure Practices and Effects on the Cost of Equity Capital : UK Evidence. Director hlm. Vol. 44

Marston, C. L., \& Shrives, P. J. 1991. The use of disclosure indices in accounting research: a review article. The British Accounting Review 23(3): 195-210.

Mehri, M., Umar, M. S., Malihi, S. A., \& Naslmosavi, S. 2013. Effects of Representational Faithfulness and Feedback Value on Cost of Equity.

Melloni, G. 2015. Intellectual capital disclosure in integrated reporting: An impression management analysis. Journal of Intellectual Capital 16(3): 661-680.

Noradiva Hamzah; Mohd Nazari Ismail. 2008. The importance of intellectual capital management in the knowledge-based economy. Contemporary Management Research 4(3): 237-262.

Orens, R., Aerts, W. \& Lybaert, N. 2009. Intellectual capital disclosure, cost of finance and firm value. Management Decision 47(10): 1536-1554.

Orens, R., Aerts, W. \& Lybaert, N. 2013. Customer value disclosure and cost of equity capital. Review of Accounting \& Finance 12(2): 130-147. 
Parnell, J. A. 2010. Competitive Strategy and Performance in Mexico, Peru, and the United States. Journal of Centrum Cathedra 3(2): 150-165.

Pitts R.; Lei, D. 2003. Strategic management: Building and sustaining competitive advantage. South-Western: Thompson.

Porter, M. E. 1980. Competitive Strategy. New York: Free Press.

Porter, Michael E. 1985. Technology and Competitive Advantage. Journal of Business Strategy 5(3): 60-78.

Roos, G. 2005. Intellectual capital and strategy: a primer for today's manager. Handbook of Business Strategy 6(1): 123-132.

Schaper, S., Nielsen, C. \& Roslender, R. 2017. Moving from irrelevant intellectual capital (IC) reporting to valuerelevant IC disclosures. Journal of Intellectual Capital 18(1): 81-101.

Setia, N., Abhayawansa, S., Joshi, M. \& Huynh, A. V. 2015. Integrated reporting in South Africa: some initial evidence. Sustainability Accounting, Management and Policy Journal 6(3): 397-424. d

Shih, K., Chang, C.-J. \& Lin, B. 2010. Assessing knowledge creation and intellectual capital in banking industry. Journal of Intellectual Capital 11(1): 74-89.

Souissi, M. \& Khlif, H. 2012. Meta-analytic review of disclosure level and cost of equity capital. International Journal of Accounting and Information Management 20(1): 49-62.

Ståhle, P. \& Bounfour, A. 2008. Understanding dynamics of intellectual capital of nations. Journal of Intellectual Capital 9(2): 164-177.

Stewart, A. T. 1997. Intellectual Capital: The New Wealth of Organizations. Bantam Doubleday Dell Publishing Group, New York, NY.

Sveiby, K. E. 1997. The New Organizational Wealth : Managing \& Measuring Knowledge-Based Assets. Berrett-Koehler Publishers, San Francisco, CA.

Tabachnick, B.G. \& Fidell, L. S. 2001. Using Multivariate Statistics, 4th ed. Needham Heights, MA: Allynand Bacon.

Teece, D. J. 2000. Strategies for managing knowledge assets: the role of firm structure and industrial context. Long range planning 33(1): 35-54.

Teeratansirikool, L., Siengthai, S., Badir, Y. \& Charoenngam, C. 2013. Competitive strategies and firm performance: the mediating role of performance measurement. International Journal of Productivity and Performance Management 62(2): 168-184.
Terblanche, W. D. V. C. 2019. The Influence of Integrated Reporting and Internationalisation on Intellectual Capital Disclosure. Journal of Intellectual Capital 20(1): 40-59.

Verrecchia, R. E. 2001. Essays on disclosure. Journal of Accounting and Economics 32(1-3): 97-180.

Villiers, C. de, Rinaldi, L. \& Unerman, J. 2014. Integrated reporting: Insights, gaps and an agenda for future research. Accounting Auditing and Accountability Journal 27(7): 1042-1067

Yolanda Ramirez Corcoles, A. T. P. 2013. Cost-benefit analysis of intellectual capital disclosure: University stakeholders' view. Revista de Contabilidad 16(2): 106-117.

Zeng, S. X., Xu, X. D., Yin, H. T. \& Tam, C. M. 2012. Factors that Drive Chinese Listed Companies in Voluntary Disclosure of Environmental Information. Journal of Business Ethics 109(3): 309-321.

Zigan, K., Macfarlane, F., \& Desombre, T. 2008. Intangible resources as performance drivers in European hospitals. International Journal of Productivity and Performance Management.

Aida Md Rashid*

Jabatan Audit Negara Malaysia

Aras 1-9, Blok F2 \& F3, Kompleks F

Lebuh Perdana Timur, Presint 1

62000 Putrajaya MALAYSIA

E-mel:jasmineaida@yahoo.com

Noradiva Hamzah

Fakulti Ekonomi dan Pengurusan

Universiti Kebangsaan Malaysia

43600 UKM Bangi, Selangor, MALAYSIA

E-mel:adibz@ukm.edu.my

Mohamat Sabri Hassan

Fakulti Ekonomi dan Pengurusan

Universiti Kebangsaan Malaysia

43600 UKM Bangi, Selangor, MALAYSIA

E-mel:msabri@ukm.edu.my

*Corresponding author 


\section{LAMPIRAN A}

SENARAI INDEKS PENDEDAHAN MODAL INTELEK

\begin{tabular}{|c|c|c|c|c|c|}
\hline BIL. & MODAL MANUSIA & & MODAL STRUKTUR & & MODAL HUBUNGAN \\
\hline 1. & Bilangan Pekerja & 23. & Harta Intelek & 41. & Pelanggan \\
\hline 2. & Umur Pekerja & 24. & Proses & 42. & Kewujudan Pasaran \\
\hline 3. & Diversiti Pekerja & 25. & Falsafah Pengurusan & 43. & Hubungan Pelanggan \\
\hline 4. & Kesamarataan Pekerja & 26. & Budaya Korporat & 44. & Pertambahan Pelanggan \\
\hline 5. & Hubungan Pekerja & 27. & Fleksibiliti Syarikat & 45. & Pengekalan Pelanggan \\
\hline 6. & Pendidikan Pekerja & 28. & Struktur Organisasi & 46. & Pendidikan \& Latihan Pelanggan \\
\hline 7. & Kemahiran & 29. & Pembelajaran Organisasi & 47. & Penglibatan Pelanggan \\
\hline 8. & Kemahiran Berkaitan Kerja & 30. & $\begin{array}{l}\text { Penyelidikan } \\
\text { Pembangunan }\end{array}$ & 48. & Imej Syarikat \\
\hline 9. & Pengetahuan Berkaitan Kerja & 31. & Inovasi & 49. & Penganugerahan syarikat \\
\hline 10. & Kelakuan Pekerja & 32. & Teknologi & 50. & Hubungan Dengan Pihak Awam \\
\hline 11. & Komitmen Pekerja & 33. & Urusan kewangan & 51. & $\begin{array}{l}\text { Penerimaan dan Jaringan } \\
\text { Rangkaian }\end{array}$ \\
\hline 12. & Motivasi Pekerja & 34. & Fungsi Sokongan Pengguna & 52. & Jenama \\
\hline 13. & Produktiviti Pekerja & 35. & $\begin{array}{l}\text { Infrastruktur Berasaskan } \\
\text { Pengetahuan }\end{array}$ & 53. & Saluran Pengedaran \\
\hline 14. & Latihan Pekerja & 36. & $\begin{array}{l}\text { Pengurusan Kualiti \& } \\
\text { Penambahbaikan }\end{array}$ & 54. & Hubungan Dengan Pembekal \\
\hline 15. & Kelayakan Vokasional & 37. & Akreditasi & 55. & Kerjasama Perniagaan \\
\hline 16. & Pembangunan Pekerja & 38. & Keupayaan infrastruktur & 56. & Perjanjian Perniagaan \\
\hline 17. & Fleksibiliti Pekerja & 39. & Jaringan Rangkaian & 57. & Kontrak Keutamaan \\
\hline 18. & Semangat Keusahawanan & 40. & Jaringan Pengedaran & 58. & Kerjasama Penyelidikan \\
\hline 19. & Keupayaan Pekerja & & & 59. & Pemasaran \\
\hline 20. & Kerja Berpasukan & & & 60. & $\begin{array}{l}\text { Hubungan Dengan Pemengang } \\
\text { Kepentingan }\end{array}$ \\
\hline 21. & $\begin{array}{l}\text { Penglibatan Pekerja Dengan } \\
\text { Masyarakat }\end{array}$ & & & 61. & Kepimpinan Pasaran \\
\hline 22. & Ciri-ciri Lain Pekerja & & & & \\
\hline
\end{tabular}

